\title{
Infrastructure and Rurality: Challenges for Sustainable Economic Development in Latin America
}

\author{
Tania Jimenez-Castilla, Ph.D. ${ }^{1}$, Luis M. Bolivar, Ph.D.(c) ${ }^{1}$, and Michael Segrera-Castilla ${ }^{1}$ \\ ${ }^{1}$ Universidad Tecnológica de Bolívar, Colombia, tjimenez@utb.edu.co, lbolivar@utb.edu.co, matt.s.castilla@gmail.com
}

\begin{abstract}
Latin America is a region with a great environmental and cultural diversity; however, most of its countries have high levels of poverty and inequality, characteristics that are accentuated in rural areas. This paper establishes that the reduction of the urbanrural gap and investment in sustainable infrastructure are the key challenges facing Latin American governments to achieve significant progress. The analysis explains that, if infrastructure projects are promoted in the region, it impacts on at least nine sustainable development goals (SDGs), which would result in a significant increase in people's well-being.
\end{abstract}

Keywords-- Sustainable infrastructure, sustainable development, poverty, inequality, rurality.

\section{INTRODUCTION}

Strategies to promote economic development in the Latin American region is in need to be aligned with the Global Sustainable Development Goals (SDGs) and, therefore, must be considered from a multidimensional approach. Latin America is one of the most unequal regions in the world, despite the great natural wealth that this region possesses; furthermore, most countries have low economic growth, high levels of incomerelated poverty and a high degree of inequality. These problems are concentrated in the rural areas of each nation, being determining factors in the slowdown in economic growth they have been experiencing, which is a trend that started in 2014 and is expected to continue in 2020 [1].

This paper establishes that the reduction of the urban-rural gap and investment in sustainable infrastructure are the key challenges facing Latin American governments to achieve significant progress. The analysis explains that, if sustainable infrastructure projects are promoted in the region, it impacts on at least nine sustainable development goals (SDGs), which would result in a significant increase in people's well-being.

\section{POVERTY AND INEQUALITY IN LATIN AMERICA}

Latin America is one of the most unequal regions in the world, despite the natural wealth that the region owns; what is more, most countries have low economic growth, high levels of income-related poverty and a high degree of inequality. These problems are concentrated in rural areas of each nation, being determining factors in the slowing economic growth they have been experiencing, which is a trend started in 2014 that is expected to continue in 2020 [1]

In its publication "Social Panorama of Latin America, 2019", Reference [2] shows the estimated income poverty and extreme poverty rates, based on household surveys from 18 countries in the region. The result of the study shows that the Digital Object Identifier (DOI):

http://dx.doi.org/10.18687/LACCEI2020.1.1.542

ISBN: 978-958-52071-4-1 ISSN: 2414-6390
Latin American region had an increase in these rates from 2014 to 2018 , with an increase in income poverty from $27.8 \%$ to $30.8 \%$ (from 164 million to approximately 185 million people) while extreme poverty increased from $7.8 \%$ to $10.7 \%$ (approximately from 46 million to 66 million people). This result is mainly due to the increases in Brazil and to a greater extent to the Bolivarian Republic of Venezuela, according to the projection made by ECLAC. The other countries in the region managed to reduce poverty levels slightly, but the effort was insufficient (see Table I).

In addition to poverty, another problem experienced by these countries is inequality, which is accentuated by the urbanrural gap and has become a challenge for national governments. The Gini index, which measures the income inequality of people in a territory or country, shows for the Latin American region on average 0.425 in 2018, in which Brazil and Colombia had results greater than 0.50 (Table II) [2].

TABLE I

EVOLUTION OF INCOME POVERTY AND MONETARY POVERTY IN LATIN AMERICA AND SOME OF ITS COUNTRIES

Source: Prepared by authors based on ECLAC's database CEPALSTAT, based on household surveys of countries. Notes: The average for Latin America was calculated by ECLAC on the basis of 18 countries (including Argentina that only has data from its urban area, Guatemala, Nicaragua and Venezuela that only present information from 2014, for these countries ECLAC uses projections or estimates in the respective years). ${ }^{\mathrm{a}} \mathrm{C}_{\text {omparable }}$ until 2015. ${ }^{\mathrm{b}}$ Comparable since $2016 .{ }^{\mathrm{c}}$ Comparable until 2016. ${ }^{\mathrm{d}}$ Comparable since 2017.

\begin{tabular}{|l|c|c|c|c|c|c|c|c|c|c|}
\hline \multirow{2}{*}{ country } & \multicolumn{4}{|c|}{ Income poverty } & \multicolumn{5}{c|}{ Extreme poverty } \\
\cline { 2 - 11 } & $\mathbf{2 0 1 4}$ & $\mathbf{2 0 1 5}$ & $\mathbf{2 0 1 6}$ & $\mathbf{2 0 1 7}$ & $\mathbf{2 0 1 8}$ & $\mathbf{2 0 1 4}$ & $\mathbf{2 0 1 5}$ & $\mathbf{2 0 1 6}$ & $\mathbf{2 0 1 7}$ & $\mathbf{2 0 1 8}$ \\
\hline Brazil & $16,5 \mathrm{a}$ & $18,8 \mathrm{a}$ & $19,8 \mathrm{~b}$ & $20,3 \mathrm{~b}$ & $19,4 \mathrm{~b}$ & $3,3 \mathrm{a}$ & $4,0 \mathrm{a}$ & $5,0 \mathrm{~b}$ & $5,5 \mathrm{~b}$ & $5,4 \mathrm{~b}$ \\
\hline Bolivia & 33,7 & 34,7 & 35,3 & 35,1 & 33,2 & 14,9 & 14,6 & 16,7 & 16,4 & 14,7 \\
\hline Chile & -- & 13,7 & -- & 10,7 & -- & -- & 1,8 & -- & 1,4 & -- \\
\hline Colombia & 31,1 & 30,5 & 30,9 & 29,8 & 29,9 & 12,0 & 11,3 & 12,0 & 10,9 & 10,8 \\
\hline Costa Rica & 17,5 & 17,3 & 16,5 & 15,4 & 16,1 & 4,1 & 4,6 & 4,2 & 3,3 & 4,0 \\
\hline Ecuador & 23,4 & 23,9 & 24,3 & 23,6 & 24,2 & 5,9 & 7,0 & 7,5 & 7,0 & 6,5 \\
\hline El Salvador & 44,5 & 42,6 & 40,4 & 37,8 & 34,5 & 11,7 & 10,4 & 10,7 & 8,3 & 7,6 \\
\hline Honduras & 55,3 & 55,2 & 53,2 & -- & 55,7 & 19,2 & 19,0 & 18,8 & -- & 19,4 \\
\hline Mexico & 45,2 & -- & 43,7 & -- & 41,5 & 13,0 & -- & 11,7 & -- & 10,6 \\
\hline Panama & 19,7 & 17,9 & 17,0 & 16,7 & 14,5 & 9,2 & 8,0 & 8,5 & 7,6 & 6,2 \\
\hline Paraguay & 22,3 & 23,4 & 24,0 & 21,6 & 19,5 & 7,7 & 7,3 & 7,9 & 6,0 & 6,5 \\
\hline Peru & 19,5 & 19,0 & 19,1 & 18,9 & 16,8 & 5,1 & 5,4 & 5,2 & 5,0 & 3,7 \\
\hline $\begin{array}{l}\text { Dominican } \\
\text { Republic }\end{array}$ & $32,9 \mathrm{c}$ & $29,6 \mathrm{c}$ & $27,3 \mathrm{c}$ & $25,0 \mathrm{~d}$ & $22,0 \mathrm{~d}$ & $9,7 \mathrm{c}$ & $9,2 \mathrm{c}$ & $7,2 \mathrm{c}$ & $6,4 \mathrm{~d}$ & $5,0 \mathrm{~d}$ \\
\hline Uruguay & 4,5 & 4,1 & 3,5 & 2,7 & 2,9 & 0,2 & 0,2 & 0,2 & 0,1 & 0,1 \\
\hline Latin America & 27,8 & 29,0 & 30,0 & 30,1 & 30,0 & 7,8 & 8,8 & 10,0 & 10,5 & 10,7 \\
\hline
\end{tabular}

18th LACCEI International Multi-Conference for Engineering, Education, and Technology: "Engineering, Integration, and Alliances for a Sustainable Development" "Hemispheric Cooperation for Competitiveness and Prosperity on a Knowledge-Based Economy", July 27-31, 2020, Virtual 
This statistic highlights the difficulties in terms of access to basic services such as energy, water, sanitation and quality education. An example of this is the data for Colombia shown in Fig. 1.

\section{A. Urban - Rural Gap in Latin America}

The Statistical Yearbook of Latin America and the Caribbean 2018, published by Reference [3] allows us to observe the gap between urban and rural areas, which is present in most countries of the region.

Except for Chile, Dominican Republic and Uruguay, the percentage of population living in income poverty and extreme poverty in Latin America show that in rural areas, it nearly doubles that in urban areas, as indicated in Fig. 2 and Fig. 3.

TABLE II

EVOLUTION OF THE GINI INEQUALITY INDEX FROM 2014-2018 IN LATIN AMERICA AND SEVERAL OF ITS COUNTRIES

Source: Prepared by the authors based on the latest available data from the indicator for each country in the World Bank (until 2017), the values recorded in 2018 and the regional averages were calculated by Reference [2].

\begin{tabular}{|l|c|c|c|c|c|c|}
\hline Country & $\mathbf{2 0 1 4}$ & $\mathbf{2 0 1 5}$ & $\mathbf{2 0 1 6}$ & $\mathbf{2 0 1 7}$ & $\mathbf{2 0 1 8}$ & Trend \\
\hline Bolivia & 0,478 & 0,467 & 0,446 & 0,44 & 0,438 & $\downarrow$ \\
\hline Brazil & 0,515 & 0,513 & 0,537 & 0,533 & 0,54 & $\uparrow$ \\
\hline Chile & -- & 0,477 & -- & 0,466 & 0,454 & $\downarrow$ \\
\hline Colombia & 0,527 & 0,511 & 0,508 & 0,497 & 0,52 & $\uparrow$ \\
\hline Costa Rica & 0,486 & 0,484 & 0,487 & 0,483 & 0,493 & $\uparrow$ \\
\hline Dominican Republic & 0,443 & 0,452 & 0,457 & -- & 0,444 & $\downarrow$ \\
\hline Ecuador & 0,45 & 0,46 & 0,45 & 0,447 & 0,454 & $\uparrow$ \\
\hline Honduras & 0,504 & 0,496 & 0,5 & 0,505 & 0,481 & $\downarrow$ \\
\hline Mexico & 0,487 & -- & 0,483 & -- & -- & \\
\hline Panama & 0,505 & 0,508 & 0,504 & 0,499 & 0,498 & $\downarrow$ \\
\hline Peru & 0,432 & 0,434 & 0,436 & 0,433 & 0,439 & $\uparrow$ \\
\hline Paraguay & 0,507 & 0,476 & 0,479 & 0,488 & 0,474 & $\downarrow$ \\
\hline El Salvador & 0,416 & 0,406 & 0,4 & 0,38 & 0,45 & $\uparrow$ \\
\hline Uruguay & 0,401 & 0,402 & 0,397 & 0,395 & 0,391 & $\downarrow$ \\
\hline $\begin{array}{l}\text { Latin America and the } \\
\text { Caribbean }\end{array}$ & 0,477 & -- & -- & 0,469 & 0,465 & $\downarrow$ \\
\hline
\end{tabular}

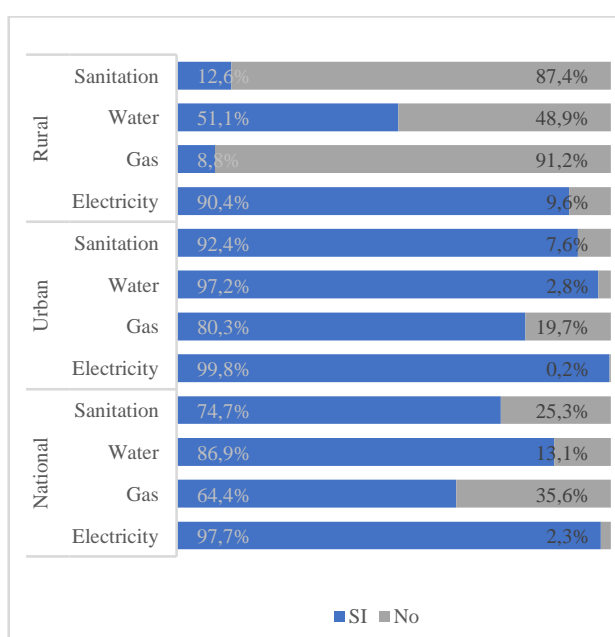

Fig. 1. Access to utilities gap between urban and rural areas in Colombia, 2018 Source: Prepared by the authors based on data from the National Survey of Quality of Life carried out by the National Administrative Department of Statistics - DANE in 2018.
Likewise, it can be seen that selected countries such as Honduras, Mexico, Bolivia, El Salvador and Colombia have the highest proportion of population living in income poverty and extreme poverty at the national level and in their respective rural areas.

Taking into account that throughout history rurality has been a source of sustenance for mankind and it is the scenario for great diversity of natural, environmental and cultural assets that can be used for the diversification of the productive matrix and enhance development [4], it remains the questions of the reasons for this urban-rural gap and for the concentration of poverty in rural areas.

Unfortunately, development in Latin America was conceived as the transition from rural to urban, and from agricultural to industrialized; however, from the sustainable development perspective, the rural environment is an area of opportunity for progress in connection with the economic processes in urban areas and transcends agricultural production, enabling progress in other industries.

For instance, the use of natural and cultural resources provides advantages for new tourism approaches (nature tourism, ethnographic tourism, historical tourism, among others), the production of sustainable alternative energy, agroindustrial goods and services trade, and ecosystem-related services.

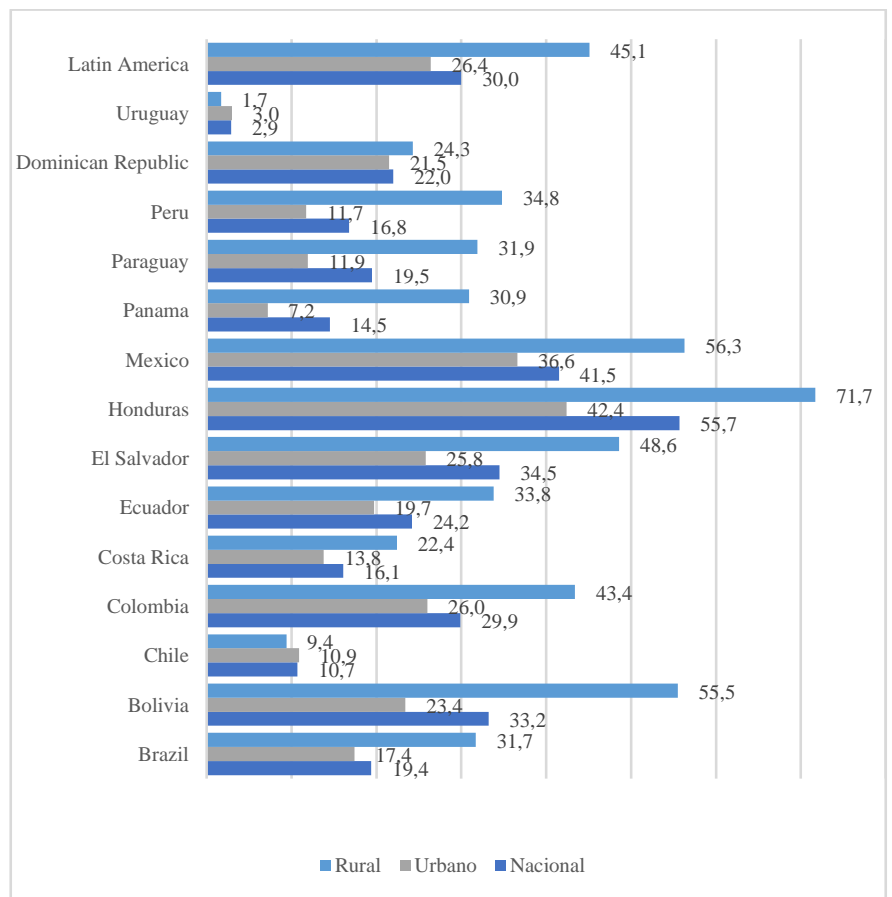

Fig. 2. Percentage of the population of Latin America and 14 countries that are in conditions of income poverty, 2017.

Source: Prepared by the authors based on data from the Statistical Yearbook of Latin America and the Caribbean, 2018 published by Reference [3]. Note: The ECLAC calculated the percentage of the region with the average weighted on the basis of information from the countries; The estimate is based on 18 countries in the region: Argentina, Bolivia, Brazil, Chile, Colombia, Costa Rica, Ecuador, El Salvador, Guatemala, Honduras, Mexico, Nicaragua, Panama, Paraguay, Peru, Venezuela, Dominican Republic and Uruguay 


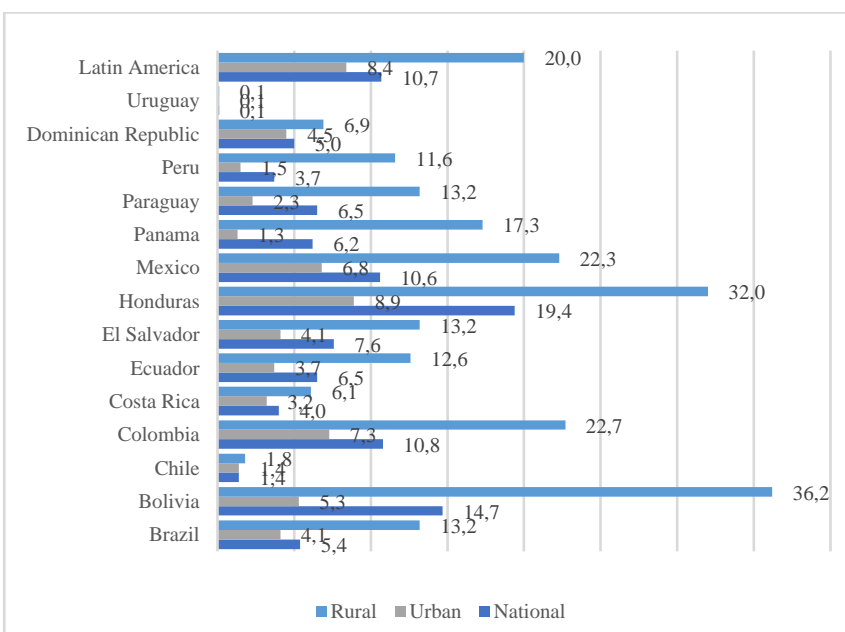

Fig. 3. Percentage of the population of Latin America and some of its countries with population under extreme poverty, 2017.

Source: Prepared by the authors based on data from the Statistical Yearbook of Latin America and the Caribbean, 2018 published by Reference [3]. Note: The ECLAC calculated the percentage of the region with the average weighted on the basis of information from the countries ; The estimate is based on 18 countries in the region: Argentina, Bolivia, Brazil, Chile, Colombia, Costa Rica, Ecuador, El Salvador, Guatemala, Honduras, Mexico, Nicaragua, Panama, Paraguay, Peru, Venezuela , Dominican Republic and Uruguay

In all the countries that make up Latin America, the extension of land area that represents the rural area is greater than the land of the urban area, however, the population is mostly concentrated in urban centers. Development policies in Latin America have focused on capitals and heads of municipalities in urban areas and as a result there has been a structural lag in rural areas, making the rural in synonymous with poverty, precariousness and vulnerability, as observed in Table III.

\section{INFRASTRUCTURE FOR CLOSING THE URBAN-RURAL GAP AND REDUCING POVERTY}

Rural development in Latin America faces difficulties due to little investment of governments in quality and sustainable infrastructure. On one hand, infrastructure is defined as "the set of engineering structures and facilities - usually with a long life cycle - that constitute the basis on which the provision of services considered necessary for the development of productive, political, social and personal purposes occurs [5]. On the other hand, quality and sustainable infrastructure is understood as one that is resilient, which has a long shelf life, which is planned harmoniously with the natural environment, and which adequately and rationally leverages the economic, environmental and financial resources.

The ninth of the Sustainable Development Goals - SDG focuses on building resilient infrastructure, promoting inclusive and sustainable industrialization and fostering innovation. This SDG has a strong influence on the other objectives and goals, mainly on poverty reduction (SDG1), the generation of clean and affordable energy (SDG7), access to clean water and sanitation (SDG6), greater access to education of quality (SDG4) and the reduction of inequalities (SDG10).

Infrastructure is the axis that articulates the economic and territorial system of a country, allowing mobility and access to goods and services, as well as innovation in new products. In consequence, well-being improves if the existing urbanrural gap is reduced and infrastructure plays a priority role in this process. As an example, the results listed in Table 1 and Table III show that sustainable infrastructure investment in rural areas is necessary to curb the concentration of population in urban areas and seize the economic potential offered by the natural and cultural development environment of territories.

In addition, inequality and high poverty indexes inherent to these rural areas may be reduced by means of infrastructure investment, given that it would improve various aspects that are affecting the quality of people's life.

For instance, the lack of access to electrical energy services, and drinking water and basic sanitation, as well as the low quality that these may have. Infrastructure investment also impacts in education quality, which indeed reveals the urbanrural gap, due to the lack of power grids and communications networks, information and communications technology - ICT, adequate classroom and sport practice spaces availability.

TABLE III

DISTRIBUTION OF LAND EXTENSION AREAS AND POPULATION IN URBAN AND RURAL AREAS, AND POVERTY INDEX OF EACH AREA FOR 2017

Source: Prepared by the authors based on data from the World Bank and the Statistical Yearbook of Latin America and the Caribbean, 2018 published by Reference [3]. Note: For comparison purposes with the other tables, Honduras and Mexico have the figures for 2016.

\begin{tabular}{|c|c|c|c|c|c|c|}
\hline \multirow[b]{2}{*}{ Country } & \multicolumn{3}{|c|}{ Urban area } & \multicolumn{3}{|c|}{ Rural area } \\
\hline & $\begin{array}{l}\text { Land area } \\
\left(\mathbf{k m}^{2}\right)\end{array}$ & $\begin{array}{l}\% \text { of } \\
\text { total } \\
\text { pop. }\end{array}$ & $\begin{array}{l}\text { Pov. } \\
\text { index }\end{array}$ & $\begin{array}{c}\text { Land area } \\
\left(\mathbf{k m}^{2}\right)\end{array}$ & $\begin{array}{l}\% \text { of } \\
\text { total } \\
\text { pop. }\end{array}$ & $\begin{array}{l}\text { Pov. } \\
\text { index }\end{array}$ \\
\hline Bolivia & -- & 69,08 & 6,5 & -- & 30,58 & 38,6 \\
\hline Brazil & $1.349 .810,38$ & 86,31 & 4,2 & $8.241 .430,00$ & 13,69 & 13,0 \\
\hline Chile & $12.027,52$ & 87,49 & 1,4 & $709.418,75$ & 12,44 & 1,8 \\
\hline Colombia & $36.132,14$ & 80,45 & 7,4 & $1.090 .598,13$ & 19,22 & 22,9 \\
\hline Costa Rica & $4.051,56$ & 78,56 & 2,7 & $46.479,98$ & 20,66 & 4,9 \\
\hline $\begin{array}{l}\text { Dominican } \\
\text { Republic } \\
\end{array}$ & $5.089,38$ & 80,28 & 5,9 & $42.784,18$ & 18,93 & 8,7 \\
\hline Ecuador & $10.905,65$ & 63,67 & 3,5 & $244.458,23$ & 36,18 & 14,4 \\
\hline Honduras* & $3.702,36$ & 55,813 & 11,4 & $108.150,58$ & 42,90 & 27,5 \\
\hline Mexico* & $102.418,11$ & 79,577 & 7,6 & $1.831 .423,50$ & 19,84 & 25,0 \\
\hline Panama & $2.892,14$ & 67,37 & 1,9 & $71.714,31$ & 32,29 & 20,4 \\
\hline Peru & $16.425,77$ & 77,72 & 2,2 & $1.256 .339,88$ & 22,09 & 12,1 \\
\hline Paraguay & -- & 61,30 & 1,7 & -- & 38,42 & 16,6 \\
\hline $\begin{array}{l}\text { El } \\
\text { Salvador }\end{array}$ & $3.598,27$ & 71,28 & 4,1 & $16.349,95$ & 27,98 & 14,7 \\
\hline Uruguay & $4.689,68$ & 95,24 & 0,1 & $168.731,92$ & 4,67 & 0,1 \\
\hline $\begin{array}{l}\text { Latam \& } \\
\text { Caribbean } \\
\end{array}$ & $462.259,61$ & 80,34 & 8,1 & $18.127 .126,26$ & 19,42 & 20,8 \\
\hline
\end{tabular}




\section{BASIC SERVICES AND RURALITY IN LATIN AMERICA}

According to the regional report on human development in Latin America and the Caribbean, published by [7], the poor infrastructure and the difficult access to utilities in rural areas makes people spend several hours a day fetching water or firewood, activities that are more frequently carried out by women than by men. On the other hand, due to the lack of appliances, the daily hours for household chores are extended; and as a consequence, the economic participation of the rural population in the labor market, especially women, is constrained.

Undeniably, access to basic utilities is essential for development. As such, the vast majority of the Latin American population have access to electricity service, according to data from the World Bank. Table IV shows the percentages of the population with access to electricity in the region, disaggregated in several countries, as well as the increases in the last four years. Chile is the regional power in the energy sector covering all of its population, both urban and rural, while the other countries show a slightly lower percentage in rural areas than in the urban area. In 2017, Brazil, the Dominican Republic, Ecuador, Mexico, Panama and Uruguay also managed to bring access to electricity to the entire population.
However, in rural areas, the price of the electricity service is high when contrasted with the income poverty and extreme poverty concentration in these areas; therefore, its inhabitants must give up the consumption of other goods and services or to minimize as much as possible energy use. In addition, the rural sector of Latin America does not have a modern and sustainable electric power service; the electrification of isolated rural communities is one of the great challenges that the region must face for the eradication of poverty. Geographical difficulties, population scattering, and the absence of policies focused on mobility and connectivity are some of the causes of rural lags.

\section{"Bringing electricity to rural schools produces improvements in infrastructure and benefits for teachers and students. For example, devices for better environmental thermal adequacy and systems for water purification can be installed. In addition, access to electrical energy enables better lighting within classrooms, allowing more hours of study, more concentration and less reading effort" [8]}

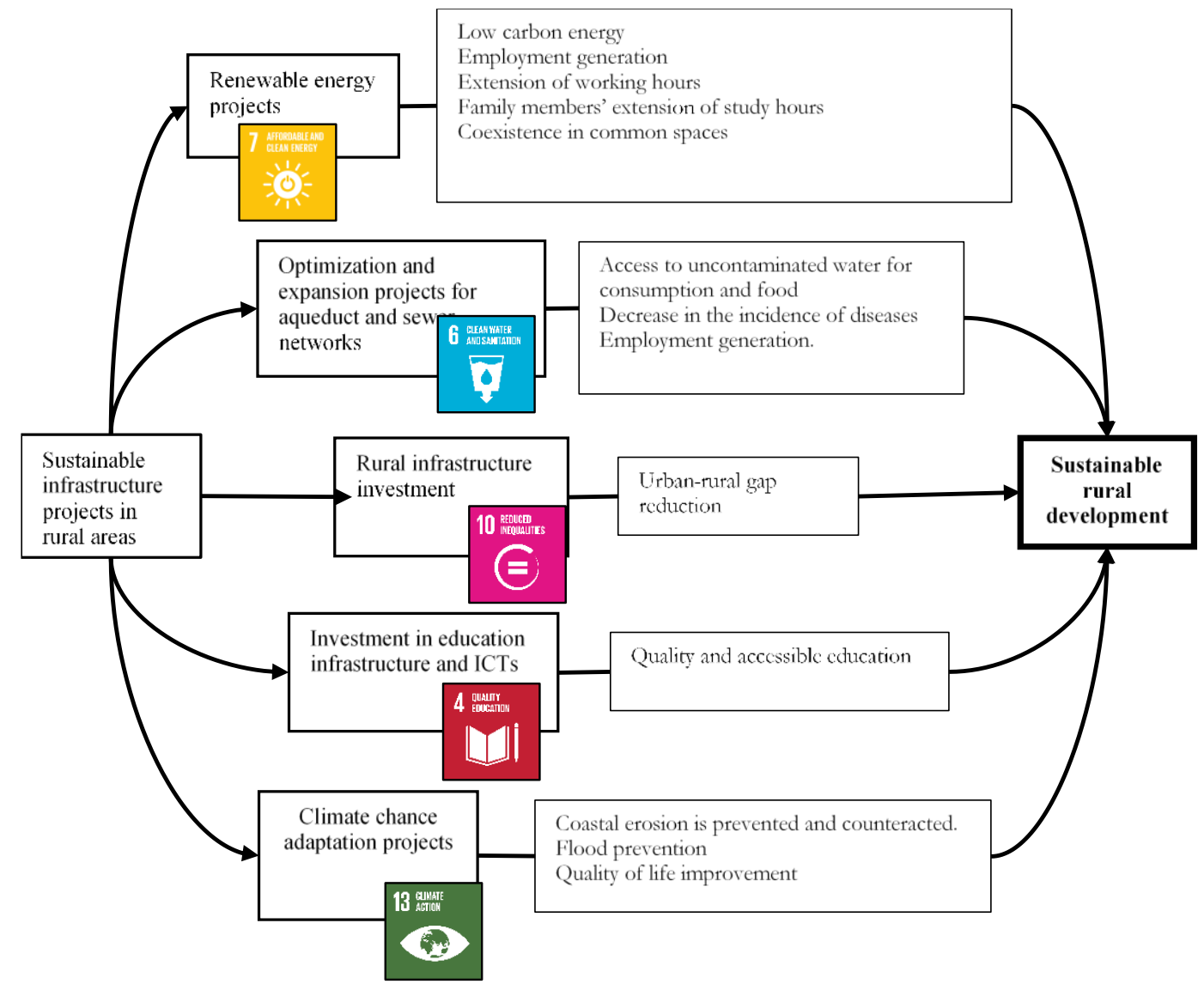

Fig. 4. Relationship of the impact of infrastructure investment on the other SDGs. Source: Prepared by the authors, in accordance with Fig. 1, in Reference [6]. 
TABLE IV

PERCENTAGE OF THE POPULATION OF LATIN AMERICA AND SOME OF ITS COUNTRIES WITH ACCESS TO THE ELECTRIC POWER SERVICE Source: Prepared by authors based on data from the World Bank.

\begin{tabular}{|c|c|c|c|c|c|c|c|c|c|c|c|c|}
\hline \multirow[t]{2}{*}{ Country } & \multicolumn{4}{|c|}{$\begin{array}{l}\begin{array}{l}\text { Percentage of the population with access } \\
\text { to electricity }\end{array} \\
\end{array}$} & \multicolumn{4}{|c|}{$\begin{array}{c}\text { Percentage of the urban population with } \\
\text { access to electricity }\end{array}$} & \multicolumn{4}{|c|}{$\begin{array}{c}\text { Percentage of the rural population with } \\
\text { access to electricity }\end{array}$} \\
\hline & 2014 & 2015 & 2016 & 2017 & 2014 & 2015 & 2016 & 2017 & 2014 & 2015 & 2016 & 2017 \\
\hline Bolivia & 90,04 & 91,52 & 91,80 & 91,80 & 99,31 & 99,46 & 99,50 & 99,40 & 70,29 & 74,34 & 74,87 & 74,82 \\
\hline Brazil & 99,65 & 99,71 & 99,70 & 100,0 & 99,95 & 99,96 & 99,90 & 100,0 & 97,91 & 98,23 & 98,47 & 100,0 \\
\hline Chile & 100,0 & 99,71 & 100,0 & 100,0 & 100,0 & 99,88 & 100,0 & 100,0 & 100,0 & 100,0 & 100,0 & 100,0 \\
\hline Colombia & 97,79 & 98,19 & 98,40 & 99,60 & 99,84 & 99,81 & 99,80 & 100,0 & 89,89 & 91,79 & 92,76 & 97,93 \\
\hline Costa Rica & 99,36 & 99,41 & 99,50 & 99,60 & 99,70 & 99,93 & 99,80 & 99,80 & 98,27 & 97,68 & 98,45 & 98,87 \\
\hline $\begin{array}{l}\text { Dominican } \\
\text { Republic }\end{array}$ & 98,47 & 98,56 & 98,90 & 100,0 & 99,86 & 99,83 & 99,90 & 100,0 & 93,64 & 93,92 & 95,04 & 100,0 \\
\hline Ecuador & 98,98 & 98,83 & 98,70 & 100,0 & 99,83 & 99,87 & 99,80 & 100,0 & 97,50 & 97,02 & 96,78 & 100,0 \\
\hline Honduras & 88,65 & 89,98 & 91,60 & 86,50 & 98,76 & 98,90 & 99,10 & 97,80 & 87,82 & 89,20 & 89,90 & 91,89 \\
\hline Mexico & 99,17 & 99,00 & 99,50 & 100,0 & 99,64 & 99,30 & 99,80 & 100,0 & 100,0 & 100,0 & 100,0 & 100,0 \\
\hline Panama & 93,73 & 94,92 & 96,82 & 100,0 & 99,15 & 99,37 & 99,59 & 100,0 & 83,04 & 86,01 & 91,19 & 100,0 \\
\hline Peru & 92,92 & 93,85 & 94,20 & 96,36 & 98,88 & 98,87 & 98,90 & 100,0 & 72,77 & 76,69 & 77,97 & 83,68 \\
\hline Paraguay & 99,00 & 99,33 & 98,40 & 99,30 & 99,83 & 99,82 & 99,90 & 99,80 & 100,0 & 100,0 & 100,0 & 100,0 \\
\hline El Salvador & 95,13 & 95,40 & 96,00 & 99,49 & 97,79 & 98,00 & 98,40 & 98,84 & 89,23 & 89,42 & 90,26 & 100,00 \\
\hline Uruguay & 99,66 & 99,71 & 99,70 & 100,0 & 99,78 & 99,81 & 99,80 & 100,0 & 100,0 & 100,0 & 100,0 & 100,0 \\
\hline $\begin{array}{l}\text { Latam \& the } \\
\text { Caribbean }\end{array}$ & 97,04 & 97,33 & 97,57 & 98,13 & 99,40 & 99,38 & 99,48 & 99,65 & 97,43 & 97,85 & 98,33 & 100,0 \\
\hline World & 85,61 & 86,80 & 88,00 & 88,87 & 96,40 & 96,63 & 97,02 & 97,36 & 73,33 & 75,40 & 77,38 & 78,68 \\
\hline
\end{tabular}

\section{A. Water and Basic Sanitation}

According to the figures from the statistical Yearbook of Latin America and the Caribbean by Reference [3], the region has greater opportunities for access to drinking water services than to basic sanitation services; in the same way rural indicators are much lower that the urban ones (Table VI), because as with the electric power services, the difficulties in the access and the dispersion of the inhabitants in the rural area, makes the task of increasing the coverage in rural areas much difficult.

In spite of the water wealth of the region, counting over $30 \%$ of global freshwater reserves, Latin America is a region in which people has difficulty accessing water services and basic sanitation quality. According to Reference [9]:

“... About 200 million people experience an intermittent water service and wastewater treatment is a pending task, since less than $20 \%$ of those waters receive some type of treatment before being reintroduced into the environment.

Hence, improving the infrastructure for access to drinking water and sanitation is essential for health and environmental protection; investment in technology enables proper management of organic waste and a lower pollution caused by these wastes, thus reducing diseases. According to Reference [9], to achieve universal access to water in 2030, the Latin American and Caribbean region would need to invest at least USD 28 billion, while sanitation investment should be greater than USD 49 billion. Table VII shows the available data for public infrastructure investment in water and sanitation in several countries in the region from 2014, where significant investment increases are not observed in infrastructure in most countries, and others have even decreased the percentage allocated to these.

TABLE V

PUBLIC INVESTMENT IN ENERGY INFRASTRUCTURE AS A PROPORTION OF GDP IN SOME LATIN AMERICAN COUNTRIES, 2014 - 2017

Source: Prepared by authors with data from the database of investment in economic infrastructure of Latin America and the Caribbean - INFRALATAM

\begin{tabular}{|l|r|r|r|r|}
\hline Country & \multicolumn{1}{|c|}{$\mathbf{2 0 1 4}$} & $\mathbf{2 0 1 5}$ & $\mathbf{2 0 1 6}$ & $\mathbf{2 0 1 7}$ \\
\hline Bolivia & $0.65 \%$ & $0.94 \%$ & $2.56 \%$ & $2.18 \%$ \\
\hline Brazil & $0.47 \%$ & $0.34 \%$ & $0.28 \%$ & $0.25 \%$ \\
\hline Colombia & $0.05 \%$ & $0.04 \%$ & $0.02 \%$ & $0.03 \%$ \\
\hline Costa Rica & $1.16 \%$ & $0.83 \%$ & $0.61 \%$ & $0.53 \%$ \\
\hline Ecuador & $2.24 \%$ & $3.02 \%$ & $2.81 \%$ & $0.00 \%$ \\
\hline Honduras & $0.49 \%$ & $0.43 \%$ & $0.62 \%$ & $0.68 \%$ \\
\hline Mexico & $0.53 \%$ & $0.58 \%$ & $1.17 \%$ & $0.22 \%$ \\
\hline Panama & $0.05 \%$ & $0.01 \%$ & $0.04 \%$ & $0.07 \%$ \\
\hline Paraguay & $0.58 \%$ & $0.60 \%$ & $0.43 \%$ & $0.53 \%$ \\
\hline Peru & $0.10 \%$ & $0.05 \%$ & $0.04 \%$ & $0.00 \%$ \\
\hline Dominican Republic & $0.59 \%$ & $0.64 \%$ & $0.85 \%$ & $1.23 \%$ \\
\hline
\end{tabular}

\section{CHALLENGES OF EDUCATION FOR SUSTAINABLE DEVELOPMENT IN LATIN AMERICA.}

The education sector is also favored through infrastructure investment; especially the one that is destined for rural electrification, drinking water and sanitation, as well as by the improvement of roads and direct investment in the adaptation of educational spaces. Thus, improving the access conditions to basic services, dropout indicators are reduced, the study day at home is extended and, in this way, the illiteracy rate could decrease. 
Reference [3] groups the percentage of the population between 15 and 24 years that does not study or work and their situation by areas (Table VIII). It can be seen from these data that the percentage of young people in this age range is higher in the rural area than in the urban areas of Latin America. This pattern is repeated in the countries selected for the analysis, except in Peru whose percentage of young population between 15 and 24 who does not study or work is higher in the urban area.

TABLE VI

PERCENTAGE OF THE POPULATION OF LATIN AMERICA AND SOME OF ITS COUNTRIES WITH ACCESS TO DRINKING WATER AND BASIC SANITATION SERVICES BY AREAS, 2017.

Source: Prepared by the authors based on data from the Statistical Yearbook of Latin America and the Caribbean, 2018 published by Reference [3].

Note: The values of Honduras and Mexico correspond to 2016, as it is the last year for which ECLAC has data on these indicators.

\begin{tabular}{|c|c|c|c|c|c|c|c|}
\hline \multirow{2}{*}{ Country } & \multirow{2}{*}{ Years } & \multicolumn{3}{|c|}{ Water service } & \multicolumn{3}{|c|}{$\begin{array}{l}\text { Basic Sanitation } \\
\text { Services }\end{array}$} \\
\hline & & National & Urban & Rural & National & Urban & Rural \\
\hline Bolivia & 2017 & 72.5 & 87.9 & 41.7 & 47.6 & 63.4 & 15.9 \\
\hline Brazil & 2017 & 90.4 & 93.0 & 73.9 & 76.9 & 75.2 & 88.3 \\
\hline Chile & 2017 & 97.1 & 99.6 & 80.1 & 93.8 & 97.0 & 71.3 \\
\hline Colombia & 2017 & 90.5 & 95.5 & 72.2 & 89.1 & 93.4 & 73.4 \\
\hline Costa Rica & 2017 & 99.4 & 99.7 & 98.7 & 48.8 & 30.8 & 96.2 \\
\hline Ecuador & 2017 & 87.8 & 95.1 & 70.8 & 78.7 & 82.1 & 71.0 \\
\hline El Salvador & 2017 & 68.2 & 70.5 & 64.4 & 43.9 & 57.1 & 21.3 \\
\hline Honduras & 2016 & 86.0 & 91.1 & 79.4 & 55.9 & 65.0 & 42.5 \\
\hline Mexico & 2016 & 92.9 & 96.1 & 81.0 & 86.9 & 89.3 & 78.1 \\
\hline Paraguay & 2017 & 66.7 & 57.6 & 81.2 & 22.1 & 15.3 & 33.2 \\
\hline Peru & 2017 & 86.6 & 91.7 & 69.8 & 76.2 & 85.9 & 44.7 \\
\hline $\begin{array}{l}\text { Dominican } \\
\text { Republic }\end{array}$ & 2017 & 87.0 & 91.7 & 68.8 & 31.7 & 25.5 & 56.1 \\
\hline Uruguay & 2017 & 97.5 & 98.0 & 89.9 & 67.5 & 65.9 & 97.3 \\
\hline Latin America & 2017 & 85.9 & 89.3 & 75.1 & 64.7 & 68 & 54.5 \\
\hline
\end{tabular}

Likewise, from the database of the Latin American Youth Observatory - JUVeLAC, it can be identified that the percentage of population that concludes their secondary school studies is significantly lower, especially in rural areas (Table IX).

Similarly, in Table $\mathrm{X}$ are displayed the number of schooling years for the population aged 25 to 59 years, where at the regional level, $29.9 \%$ of the population has between 6 and 9 years of schooling, $27.3 \%$ of the population reaches 10 to 12 years of schooling, while $20,1 \%$ of the population in this group has schooling of five years or less.

TABLE VII

PUBLIC INVESTMENT IN INFRASTRUCTURE IN DRINKING WATER AND SANITATION AS A PROPORTION OF GDP IN SOME LATIN AMERICAN COUNTRIES, 2014 - 2017.

Source: Prepared by authors with data from the database of investment in economic infrastructure of Latin America and the Caribbean - INFRALATAM.

\begin{tabular}{|l|c|c|c|c|}
\hline Country & $\mathbf{2 0 1 4}$ & $\mathbf{2 0 1 5}$ & $\mathbf{2 0 1 6}$ & $\mathbf{2 0 1 7}$ \\
\hline Bolivia & $1.05 \%$ & $0.90 \%$ & $0.68 \%$ & $0.70 \%$ \\
\hline Brazil & $0.07 \%$ & $0.04 \%$ & $0.06 \%$ & $0.06 \%$ \\
\hline Colombia & $0.46 \%$ & $0.67 \%$ & $0.70 \%$ & $0.37 \%$ \\
\hline Costa Rica & $0.14 \%$ & $0.15 \%$ & $0.13 \%$ & $0.16 \%$ \\
\hline Ecuador & $0.43 \%$ & $0.67 \%$ & $0.19 \%$ & - \\
\hline Honduras & $0.03 \%$ & $0.04 \%$ & $0.10 \%$ & $0.04 \%$ \\
\hline Mexico & $0.18 \%$ & $0.13 \%$ & $0.11 \%$ & $0.07 \%$ \\
\hline Panama & $0.56 \%$ & $0.21 \%$ & $0.10 \%$ & $0.21 \%$ \\
\hline Paraguay & $0.05 \%$ & $0.09 \%$ & $0.08 \%$ & $0.10 \%$ \\
\hline Peru & $0.63 \%$ & $0.47 \%$ & $0.28 \%$ & - \\
\hline Dominican Republic & $0.09 \%$ & $0.08 \%$ & $0.08 \%$ & $0.12 \%$ \\
\hline
\end{tabular}

TABLE VIII

PERCENTAGE OF THE POPULATION OF LATIN AMERICA BETWEEN 15 AND 24 YEARS WHO DO NOT STUDY OR WORK, BY AREAS, 2017. Source: Prepared by the authors based on data from the Statistical Yearbook of Latin America and the Caribbean, 2018 published by Reference [3]. Note: The values of Honduras and Mexico correspond to 2016, as it is the last year for which ECLAC has data on these indicators

\begin{tabular}{|c|c|c|c|c|c|c|c|c|c|}
\hline \multirow{3}{*}{ Country } & \multicolumn{3}{|c|}{ National } & \multicolumn{3}{|c|}{ Urban } & \multicolumn{3}{|c|}{ Rural } \\
\hline & \multicolumn{9}{|c|}{ Age groups } \\
\hline & $15-24$ & $15-19$ & $20-24$ & $15-24$ & $15-19$ & $20-24$ & $15-24$ & $15-19$ & $20-24$ \\
\hline Bolivia & 10.3 & 4.9 & 16.5 & 10.0 & 5.1 & 15.0 & 11.2 & 4.4 & 23.6 \\
\hline Chile & 16.0 & 10.9 & 20.4 & 15.7 & 10.9 & 19.6 & 18.8 & 10.7 & 27.1 \\
\hline Colombia & 20.5 & 16.9 & 24.1 & 19.4 & 16.0 & 22.6 & 24.5 & 19.8 & 30.0 \\
\hline El Salvador & 24.6 & 18.4 & 30.8 & 20.4 & 14.1 & 26.3 & 30.5 & 24.0 & 37.7 \\
\hline Honduras & 26.6 & 24.2 & 29.5 & 22.9 & 20.1 & 26.0 & 31.0 & 28.6 & 34.4 \\
\hline Mexico & 16.6 & 13.4 & 20.0 & 15.1 & 12.3 & 18.1 & 21.6 & 17.0 & 27.3 \\
\hline \begin{tabular}{|l|} 
Panama \\
\end{tabular} & 16.7 & 12.3 & 21.9 & 15.0 & 10.2 & 20.4 & 20.3 & 16.5 & 25.7 \\
\hline Paraguay & 16.5 & 14.3 & 18.9 & 13.3 & 11.6 & 14.8 & 22.3 & 18.3 & 27.5 \\
\hline
\end{tabular}

$18^{\text {th }}$ LACCEI International Multi-Conference for Engineering, Education, and Technology: "Engineering, Integration, and Alliances for a Sustainable Development" "Hemispheric Cooperation for Competitiveness and Prosperity on a Knowledge-Based Economy", 29-31 July 2020, Buenos Aires, Argentina. 
TABLE IX

PERCENTAGES OF POPULATION BY AREA THAT COMPLETED PRIMARY AND SECONDARY SCHOOL STUDIES, 2016.

Source: Prepared by the authors with data from the Latin American Youth Observatory (JUVeLAC), with information on household surveys by country. Note: The regional average was estimated with data from 18 countries.

\begin{tabular}{|l|c|c|c|c|}
\hline \multirow{2}{*}{\multicolumn{1}{c|}{ Country }} & \multicolumn{2}{c|}{ Primary education } & \multicolumn{2}{c|}{ Secondary Education } \\
\cline { 2 - 5 } & Urban & Rural & Urban & Rural \\
\hline Bolivia & 81.5 & 48.4 & 61.1 & 20.8 \\
\hline Brazil & 86.1 & 64.5 & 55.4 & 23.2 \\
\hline Chile & 91.5 & 78.1 & 72.0 & 42.7 \\
\hline Colombia & 86.7 & 62.4 & 63.4 & 25.9 \\
\hline Costa Rica & 88.0 & 75.2 & 48.2 & 25.6 \\
\hline $\begin{array}{l}\text { Dominican } \\
\text { Republic }\end{array}$ & 79.5 & 61.0 & 50.1 & 27.5 \\
\hline Ecuador & 91.0 & 76.6 & 58.1 & 29.3 \\
\hline Honduras & 79.4 & 57.2 & 37.7 & 11.2 \\
\hline Mexico & 87.4 & 69.6 & 43.7 & 16.8 \\
\hline Panama & 94.6 & 74.1 & 64.4 & 27.8 \\
\hline Peru & 82.6 & 53.2 & 71.0 & 27.1 \\
\hline Paraguay & 87.3 & 67.3 & 55.5 & 22.3 \\
\hline El Salvador & 76.2 & 50.9 & 42.0 & 12.4 \\
\hline Uruguay & 91.9 & 85.3 & 32.8 & 16.6 \\
\hline Latin America* & 86.6 & 63.0 & 54.9 & 21.2 \\
\hline
\end{tabular}

According to the regional report on human development for Latin America and the Caribbean, published by the United Nations Development Program - UNDP [7], it is necessary to expand the quality and equity of the education sector in rural areas, in the field of primary and secondary education, and also to ensure access to technical training programs and work skills appropriate to the offer of formal work that can be created in rural areas.

\section{CONCLUSIONS}

This work contributes to the global discussion around regional challenges for the fulfillment of the SDGs and serves as the basis for country or sub-national focused studies. As could be seen from the analysis, progress and well-being are possible only if they are studied from a multidimensional perspective. The results show that the indicators associated with poverty (SDG 1), health (SDG 3), quality of education (SDG 4 ), access to drinking water and sewerage (SDG 6), sustainable energy (SDG 7), employment ( SDG 8), inequalities (SDG 10), coastal erosion (SDG 13) and environmental impacts (SDG 15), concentrate the information related to the biggest problems for sustainable development and these challenges are accentuated in rural areas. Similarly, it is explained that tackling these problems requires the implementation of large investments in sustainable infrastructure that overcome the precarious conditions that characterize rural areas.

Consequently, it is necessary to design, promote and execute a regional agenda that aims to reduce the gap between rural and urban areas, and that has a social commitment with the ability to transcend government terms. Therefore, international alliances are required for the implementation of rural programs and projects aimed at improving the quality of life of people in the countries of the region.

TABLE X

PERCENTAGE OF THE POPULATION FROM 25 TO 59 YEARS OF AGE ACCORDING TO THEIR YEARS OF SCHOOLING, 2017.

Source: Prepared by the authors based on data from the Statistical Yearbook of Latin America and the Caribbean, 2018 published by the Economic Commission of Latin America and the Caribbean - ECLAC (2019b). Note: The values of Honduras and Mexico correspond to 2016, as it is the last year for which ECLAC has data on these indicators.

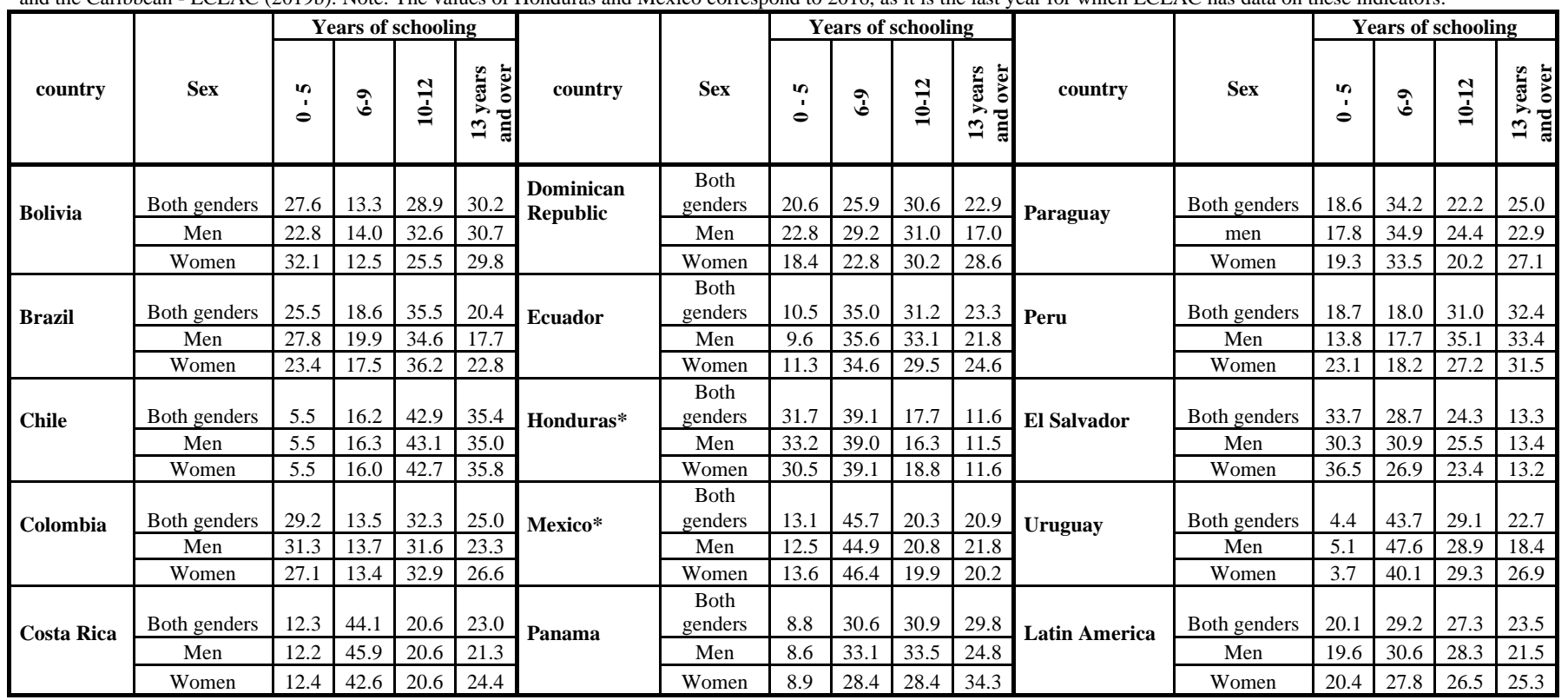

$18^{\text {th }}$ LACCEI International Multi-Conference for Engineering, Education, and Technology: "Engineering, Integration, and Alliances for a Sustainable Development" "Hemispheric Cooperation for Competitiveness and Prosperity on a Knowledge-Based Economy", 29-31 July 2020, Buenos Aires, Argentina. 


\section{REFERENCES}

[1] ECLAC, "The general slowdown persists in Latin America and the Caribbean in 2019 and low growth is expected by $2020<$ Persiste la desaceleración generalizada en América Latina y el Caribe en 2019 y se espera un bajo crecimiento para 2020>," Economic Commission for Latin America and the Caribbean, 2019. [Online]. Available: https://www.cepal.org/es/comunicados/persiste-ladesaceleracion-generalizada-america-latina-caribe2019-se-espera-un. [Accessed: 14-Apr-2019].

[2] ECLAC, "Social Panorama of Latin America, 2019," Santiago, 2019.

[3] ECLAC, "Statistical Yearbook of Latin America and the Caribbean, 2018," Santiago, 2019.

[4] T. I. Jimenez, "Renewable energies and community tourism: a joint commitment to the sustainable human development of rural communities," Rev. Energética, vol. 44, pp. 93-105, 2014.

[5] R. Sanchez, L. Jeannette, and P. Chauvet, "Infrastructure investments in Latin America: Trends, gaps and opportunities.," Santiago, 2017.

[6] T. I. Jimenez, L. M. Bolivar, and M. Segrera, "Sustainable Development in Colombia: Challenges for Compliance with the 2030 Agenda," in Economic Policies for Development: Beyond the Millennium Goals, Madrid, 2020, p. Chapter 12.

[7] UNDP, "Multidimensional progress: wellbeing beyond income. Regional Report on Human Development for Latin America and the Caribbean.," Santiago, 2016.

[8] A. Novaes, R. Mendes, and M. Hallack, "Light for rural education: more energy to reduce school dropout $<$ Luz para la educación rural: más energía para reducir el abandono escolar>," Interamerican Development Bank, 2019. [Online]. Available: https://blogs.iadb.org/energia/es/una-luz-para-laeducacion-rural-mas-energia/. [Accessed: 14-Apr2019].

[9] S. I. Campos, "Full of water, but thirsty: the future of water in Latin America and the Caribbean 'Llenos de agua, pero con sed: el futuro del agua en América Latina y el Caribe,"' Interamerican Development Bank, 2019. [Online]. Available: https://blogs.iadb.org/agua/es/3504/. [Accessed: 14Apr-2019]. 